\title{
Spatial impacts of fiscal stimulus policies during the 2009 global financial crisis in Indonesia
}

\author{
Budy P. Resosudarmo ${ }^{1}$ D $\cdot$ Abdurohman $^{2} \cdot$ Arief A. Yusuf $^{3}$ D $\cdot$ Djoni Hartono $^{4}$ (D
}

Received: 3 June 2019 / Accepted: 30 September 2020 / Published online: 15 October 2020

(c) The Japan Section of the Regional Science Association International 2020

\begin{abstract}
In response to the 2008/2009 global financial crisis (GFC), many developing countries, including Indonesia, launched fiscal stimulus packages (FSP). These FSPs typically consist of several sophisticated fiscal policies that may not necessarily complement each other. While the impact of these policies at the aggregate country level in developed countries has been widely discussed, the spatial impact of these policies within developing countries is less understood. Utilizing an inter-regional computable general equilibrium (CGE) model, this paper aims to assess and understand the short- and long-term economic impacts of these stimulus policies using Indonesia as a case study. This paper, hence, provides a quantitative ex-post assessment of FSPs typically implemented during the 2009 GFC by developing economies. Overall, results, indicate that fiscal stimulus had a positive impact on aggregate demand and on poverty prevention, principally via stimulating private consumption. Corporate income tax cuts have the largest economic impact in the long-run, and cash transfers are the most useful policy tool for alleviating poverty. An FSP, however, could have an uneven spatial distributional effect on output across regions, particularly in the short-term.
\end{abstract}

Keywords Economic crisis · Fiscal stimulus - Spatial general equilibrium model · Macro-micro-economic model

JEL classification $\mathrm{R} 13 \cdot \mathrm{H} 12 \cdot \mathrm{O} 23 \cdot \mathrm{E} 62 \cdot \mathrm{C} 68 \cdot \mathrm{D} 58$

Budy P. Resosudarmo

budy.resosudarmo@anu.edu.au

1 Arndt Corden Department of Economics, Crawford School of Public Policy, Australian National University, Canberra, Australia

2 Indonesian Ministry of Finance, Jakarta, Indonesia

3 Faculty of Economics and Business, Padjadjaran University, Bandung, Indonesia

4 Faculty of Economics and Business, University of Indonesia, Depok, Indonesia 


\section{Introduction}

The global financial crisis (GFC) that initially erupted in USA in late 2008 affected economic activities around the world. The GFC precipitated a fall in global economic growth from 5.4 in 2007 to $2.9 \%$ in 2008 , before finally causing a contraction of $0.5 \%$ in 2009, the biggest shock since the Great Depression in the 1930s (IMF 2010). The weakening of the global economy was also reflected in the 2009 substantial fall in world trade volume (10.9\%) on the back of weaker import demand in advanced countries, particularly the US, the European Union, and Japan.

In response to this 2008/2009 GFC, many developing countries launched fiscal stimulus packages (FSP) that were significantly large relative to their GDPs. Indonesia was among those countries that responded to the GFC through expansionary fiscal policy. In early 2009, the Government and the House of Representatives agreed to launch a fiscal stimulus package amounting to IDR 73.3 trillion (USD 7 billion), or $1.4 \%$ of the GDP (Ministry of Finance 2009). There were three main goals of the FSP; sustain public purchasing power through personal income tax cuts, maintain business resilience and competitiveness through various tax cuts and incentives, and to create jobs and mitigate job losses through government infrastructure projects. Furthermore, the Indonesian government distributed cash transfers to the neediest groups (i.e., the poor and nearly poor households) as much as IDR 3.8 trillion in total to help them to go through this difficult period. These policy measures were expected to boost domestic aggregate demand amidst the ailing global economy.

There have been doubts as to whether the FSP helped in navigating Indonesia through the GFC. For instance, Basri and Rahardja (2010) and Patunru and Zetha (2010) pointed out that a major factor in Indonesia's survival in the GFC was due to the "good luck" of the economy's structure (low trade dependence), rather than due to its FSP. Also, the Indonesian government was not able to fully fund the FSP implementation through deficits only (i.e., government borrowing). ${ }^{1}$ The government had to reallocate budgets for some expenditures, typically for government official travels, meetings, maintenance of government buildings and other assets, as well as research and development, to the FSP budget. In other words, the Indonesian FSP was not fully an injection of external funding. Nevertheless, the discussion of the effect of the 2009 FSP on Indonesia's economy has never been supported by any empirical evidence.

Globally, the impacts of FSP policies at the aggregate country level have been widely discussed. Theoretical discussion on the effectiveness of fiscal policies under different assumptions, mainly represented by Keynesian and Neo-Classical schools of thought, can be found in Hemming et al. (2002). Additionally, Corden $(2010,2011)$ provides detailed theoretical discussions on the effectiveness of fiscal stimulus during the 2008 GFC. While the earlier work discusses the conceptual framework of fiscal stimulus along with basic functional form and its inter-temporal

\footnotetext{
1 Borrowing from the financial market was extremely costly as government bond yield (10 years) shot up from 8.3 in January 2008 to $17.3 \%$ in October 2008; and remained at double digit for the whole year of 2009.
} 
effects, the latter provides a detailed discussion on the pros and cons of the practical aspects of fiscal stimulus.

Earlier empirical works utilizing a Computable General Equilibrium (CGE) model to assess the effect of fiscal policy on the economy were conducted by, among others, Thorbecke (1991) and Lambert et al. (1991). Both used the CGE model to assess the effect of structural adjustment policy in Indonesia and the Cote d'Ivoire, respectively. The CGE model has also been utilized to assess the effectiveness of the FSP in stimulating domestic economic activity that has been dampened by the GFC. Giesecke and Schilling (2010), Diao et al. (2012), and Zhou et al. (2011) are among those who used the single-country CGE model to investigate the economic effect of the FSP.

The spatial impacts of these policies within those countries, however, have been less understood. Using Indonesia as the case study, this paper aims to fill the gaps left by a lack of empirical evidence supporting discussions related to the impacts of the 2009 FSP on Indonesia, as well as insufficient spatial analysis in countries that implemented FSP policies in response to the 2008/2009 GFC.

This paper also provides a comparative analysis of the relative effectiveness of alternative fiscal instruments that the government might employ under the FSP scheme. The five key fiscal instruments used under the 2009 FSP are: (i) personal income tax cuts, (ii) corporate income tax cuts, (iii) indirect tax cuts, (iv) central government spending on infrastructure, and (v) cash transfers to poor and nearly poor households. ${ }^{2}$ A recursive (sequential) computable general equilibrium (CGE) model simulating the Indonesian economy till 2020 will be utilized in this paper. Hence, this paper is able to capture the short-term as well as the long-term effect of the 2009 FSP.

To achieve these goals, this paper modifies a CGE model for Indonesia called the IRSA-Indonesia5 (Resosudarmo et al.2011) to evaluate the 2009 FSP implemented in Indonesia. By doing so, this paper provides a quantitative ex-post assessment of the 2009 Indonesian FSP, which is rarely found in Indonesian economic literature.

Indonesia's response to the 2008/2009 GFC provides valuable lessons for other developing countries in response to slowing of the global economy in future; including the 2020 global crisis due to the Coronavirus pandemic. One important distinction between the 2009 Indonesian FSP compared to FSPs taken by developed countries is that Indonesia (and many other developing countries) had to reallocate some of its expenditure to fund the FSP.

The next section will discuss the CGE model utilized in this paper and its data source. This paper then provides a section on the simulation scenarios, describing in detail the simulations implemented to stimulate the Indonesian FSP policy. This

\footnotetext{
2 The cash transfer which was still delivered to the poor and nearly poor households in January and February 2009 was not officially part of the 2009 FSP. However, we decided to include it in the analysis as it is a targeted policy which has a potentially more direct effect. Such a policy is also often used as a key instrument in many countries under the FSP scheme, although, normally, it is through taxation schemes such as tax rebate in USA in 2001 (Saphiro and Slemrod 2003) and tax bonus in Australia in 2009 (Leigh 2012). For most developing countries that have an underdeveloped tax system, cash transfer through taxation is not possible, since the targeted groups are beyond the system.
} 
is followed by the Results and discussion section that will analyze the impact of the Indonesian FSP at the aggregate national level and at the spatial inter-regional levels. Finally, this paper ends with a conclusion based on its findings.

\section{IRSA-Indonesia5 model and source of data}

The IRSA-Indonesia5 is a multi-year (dynamic) and a multi-region CGE model that uses a bottom-up approach in which the model is solved at the regional level and then aggregated at the national level. It captures 5 regions consisting of Indonesia's main islands, namely Sumatra, Java-Bali, Kalimantan, Sulawesi, and Eastern Indonesia which consists of Papua, Maluku, and other small islands. The origin of the CGE model in this paper can be traced back to the work by Dervis et al. (1982) and Adelman and Robinson (1988). These models have strong roots in Walrasian general equilibrium and neoclassical real-trade theory. These models are, sometimes, referred to as "neoclassical structuralist" CGE models (Robinson, 1991). The early work on multi-region of these types of CGE were developed by Resosudarmo et al. (1999), Adelman and Yeldan (2000), Kim and Kim (2002), and Tokunaga, Resosudarmo, Wuryanto and Dung (2003). ${ }^{3}$ The IRSA-Indonesia5 runs using the GAMS Software. The work by Lofgren et al. (2002) has been used as the reference in writing this model in the GAMS Software.

The IRSA-Indonesia5 uses the Indonesian Regional Social Accounting Matrix (IRSAM) database allowing the model to capture the flow of commodities, primary factors, and transfers (Resosudarmo et al. 2009). The model can also portray the effect of a specific shock occurring at the national level, across regional levels, or with regard to one particular region. Thus, the connections between regions are through these three flows that can be among households, among governments, or between governments and households. Another important feature of the model is that each region is also connected with the rest of the world, i.e., regions conduct imports and exports with other countries as well as money transfers to or from abroad.

Basic commodity flows in the IRSA-Indonesia5 can be seen in Fig. 1. ${ }^{4}$ XTOT(i,r) represents output produced by industry $i$ in region $r$, while $\operatorname{XPRIM}(\mathrm{i}, \mathrm{d})$ and XINT_S(c,i,d) represent primary and intermediate input demand of the corresponding industry and region, respectively. Using the Leontief production function, each industry maximizes its profit by choosing the least-cost combination of inputs, and composite of primary [XPRIM(i,d)] and intermediate inputs [XINT_S(c,i,d)]. The outputs are then allocated to regional users $[\operatorname{XTRAD}(\mathrm{c}, \mathrm{r}, \mathrm{d})]$, and national users [XTRADN(c,r)]. The remainder is used for stock [XSTCK(c,r)].

\footnotetext{
${ }^{3}$ Different types of CGE models exist. The earliest one is by Johansen (1960). Within Johansen's model, the earliest bottom-up multi-regional CGE model is by Liew (1981).

4 Detailed equations and GAMS syntax codes utilized in this paper is available upon request to the authors.
} 


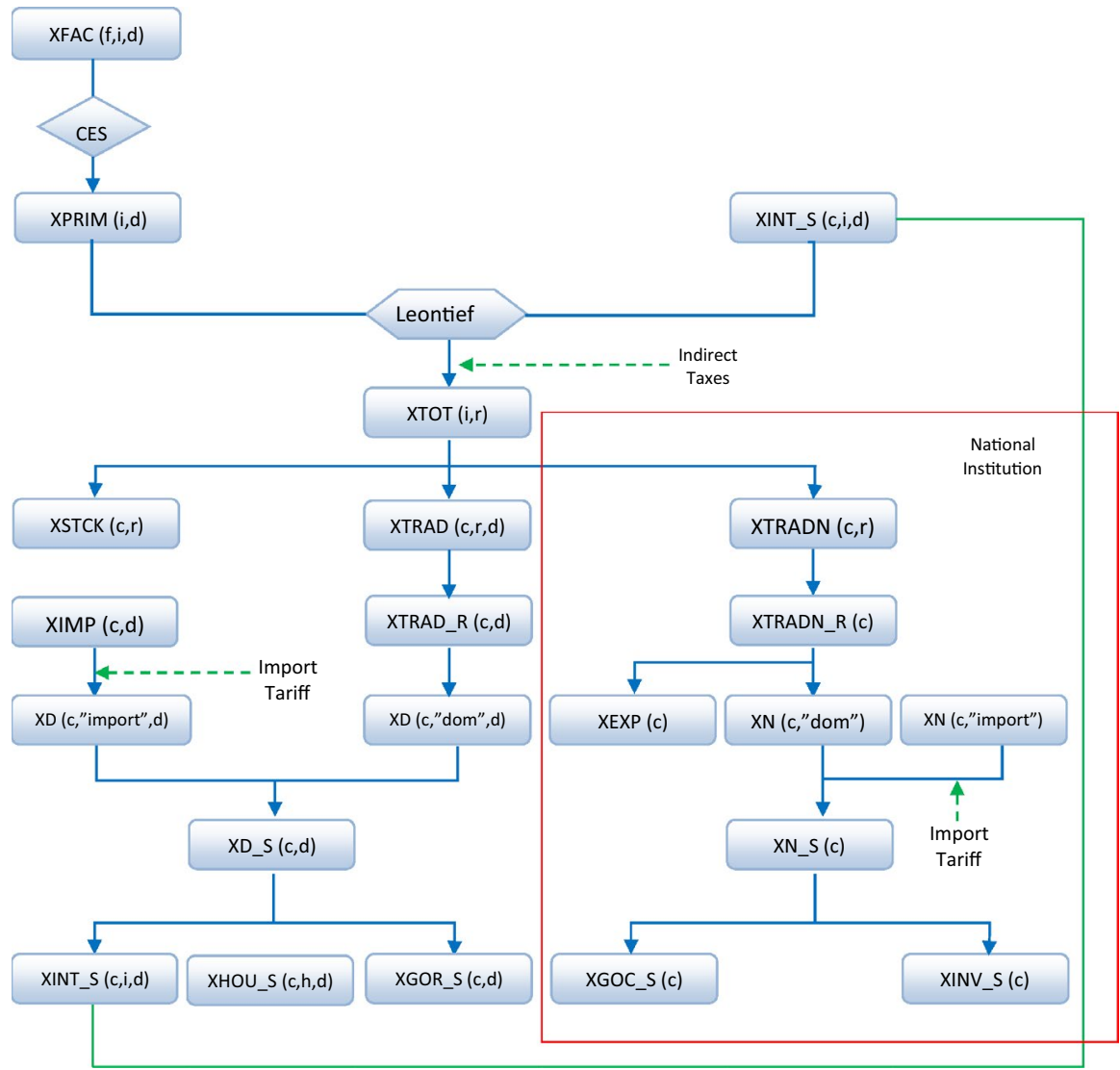

Note: Subscript notations are defined as following:

c commodity

$d$ destination of commodity in domestic region

$f$ factor of productions (labour, capital and land)

$h$ households

$i$ industry

$r$ source of commodity in domestic region

$s$ source of commodity, composite between domestic ("dom") and import ("import")

Fig. 1 Structure of production and supply

The supply of domestically produced output for a particular region [XD(c,"dom",d)] along with the imported goods to that region [XD(c,"import",d)] form the composite demand for output for that region [XD_S(c,D)], which is used for intermediate goods [XINT_S(c,i,d)] by industries and for consumption by households [XHOU_S(c,h,d)] and regional government [XGOR_S(c,d)]. Meanwhile, output that flows to national users [XTRADN $(\mathrm{c}, \mathrm{r})]$ is used both to supply national demand $[\mathrm{XN}(\mathrm{c}$, , dom")] and foreign demand (export) [XEXP(c)]. Domestically produced output for national demand combined with imported goods [XN(c,"import")] 
form the total supply for composite national demand [XN_S(c)] which is used for central government consumption [XGOC_S(c)] and aggregate investment [XINVEST_S(c)]. Note that indirect taxes affect output production, while import taxes affect composite demand. Lists of sectors and factor inputs are available in Appendix Table 6.

The IRSA-Indonesia5 is an open economy CGE model; it adopts the standard the Armington assumption, which implies that imports/domestic demand and exports/ domestic supply are imperfect substitutes (Dixon et al. 1982).

The pattern of optimization problems for households is similar to that for industry. Commodities that households demand come from various domestic regions as well as from imports. Households maximize their Stone-Geary utility function with respect to their budget constraints by finding the demand for every specific commodity as a composite of domestically produced goods and imports.

Closures which are assumptions made to close the mathematical system (model), such that the number of equations is equal to the number of unknown variables, are as follows:

(1) Total factor supplies are exogenous.

(2) All labor is mobile within an island, but not between islands within a year. Migration is exogenously determined.

(3) Land and capital are immobile.

(4) All household and corporate savings rates are exogenous, ${ }^{5}$ while government saving is residual.

(5) All shares of inter-institutional transfer rates are exogenous.

(6) World import prices are exogenous.

(7) Indirect tax and import tariff rates are exogenous.

(8) Output price index is set as a numeraire.

Labour supply and capital accumulation equations are the dynamic equations in the model. Different annual growth rates are assigned to different types of labour in each region. Each year, the country's total new capital investment is distributed to all sectors in each region. This new capital in each sector is then added to the depreciated existing capital to form the new total capital for the sector in the following year.

To assess the impact of the FSP in Indonesia, for simulating the short-term situation, this paper applies two different types of closure on the labor market. First, this paper applies the neoclassical type of closure with a full-employment assumption. Later, the Keynesian type of closure will be applied, which assumes the existence of wage rigidity implying the non-full-employment assumption. The outcomes of both types of closure are reported and compared. For simulating the long-term situation, this paper only applies the neoclassical type of closure; a full-employment/flexible wage rate assumption. ${ }^{6}$

\footnotetext{
5 During a period of a crisis, household saving rates typically would decline. Since household saving rates in Indonesia have been relatively low, this paper keeps those rates unchanged during simulations.

${ }^{6}$ Assuming wage rate is still sticky in the long term does not seem to be appropriated.
} 
The IRSA-Indonesia5 model is connected to a top-down income-distributional microsimulation module to disaggregate the two household types in the model, namely Rural Household and Urban Household, into one hundred groups based on population percentile groups in both rural and urban areas. The income of these disaggregated households is determined by a share parameter distributing the income of the original households available from the National Socio-Economic Survey (SUSENAS). Expenditure for each of these 100 households is calculated using a linear expenditure system (LES) demand function derived from the Stone-Geary utility function. Poverty incident, then, is calculated based on the incomes of these 100 household groups in rural and urban areas (Yusuf and Resosudarmo 2015).

The database of the IRSA-Indonesia5 is the 2005 Indonesian inter-regional social accounting matrix (IRSAM) constructed by Resosudarmo et al. (2009). The 2005 IRSAM table for Indonesia is constructed mainly from the 2005 inter-regional input-output (IRIO) table developed by the Indonesian Statistical Agency (BPS) combined with other additional data such as SUSENAS, National Labor Force Survey (SAKERNAS), Population Census, and some other regional data. These additional data are used to transform the IRIO table into the IRSAM table.

For the dynamic component of the IRSA-Indonesia5, data on population, labour supply, and economic growth both at the national and regional levels are available from the Indonesian Statistics Agency (BPS). Meanwhile, data of the 2009 FSP and its components come from the Ministry of Finance of the Republic of Indonesia.

\section{Simulation scenarios}

The impact of the weakening global economy transmitted through international trade and capital flow channels are taken into account. The earlier channel is reflected in the decline in international commodity prices, while the latter is reflected in the decrease of capital inflow as well as remittance. In this paper, the export price of Indonesian commodities is simulated to drop by $10 \%$, while the import price is simulated to drop by $5 \%$. Both capital inflow and remittance decrease by $2.5 \%{ }^{7}$ In addition, weakening of the global economy is simulated to last 5 years, which means that the price of exports, imports, capital inflow, and remittance resume at the pre-crisis level during 2013.

The outline of the 2009 FSP is presented in Table 1. The 2009 Indonesian FSP is comprised of five major components according to each target goal. Having captured the impact of the GFC in the model, policy simulations are then developed to understand the effectiveness of the FSP. This is done by setting two scenarios; the existing policy scenario (SIM1) and the no-policy scenario (SIM0). The second step is to evaluate the relative effectiveness of each fiscal stimulus instrument in stimulating the economy. To do this, five other policy scenarios representing each fiscal stimulus instrument used under the 2009 FSP are explored.

\footnotetext{
7 The magnitude of the shocks is based on data for all Asian Developing economies, not specifically for Indonesia, based on the World Economic Outlook 2011 (IMF 2011).
} 
Table 1 Major fiscal stimulus package in Indonesia (IDR trillion)

\begin{tabular}{lccl}
\hline Major stimulus measures & Planned & Realized & $\begin{array}{l}\text { Proportion } \\
\text { of base value } \\
(\%)\end{array}$ \\
\hline Personal income tax saving & & & 30.3 \\
Lower personal income tax rate & 24.5 & 24.5 & - \\
Higher non-taxable income threshold & 13.5 & 13.5 & - \\
Corporate income tax saving & 11.0 & 11.0 & 4.2 \\
Tax rate cut (30->28\%) & 25.8 & 19.5 & - \\
Subsidy on corporate income tax & 18.5 & 18.5 & - \\
Indirect tax saving & 7.3 & 1.0 & 2.1 \\
Infrastructure spending & 10.8 & 6.0 & 1.7 \\
Public work infrastructure & 12.2 & 10.6 & - \\
Transportation infrastructure & 6.6 & 6.4 & - \\
Other construction & 2.2 & 2.1 & - \\
Total 2009 FSP & 3.4 & 2.1 & - \\
Cash transfer in 2009 & 73.3 & 60.6 & 14.4 \\
\hline
\end{tabular}

Cash transfer is not officially part of the 2009 FSP. However, it is usually one of the important fiscal stimulus measures in many advanced countries such as Australia and US. Base value means the original value of the item before the fiscal stimulus. For example, personal income tax is expected to be as high as IDR 80.7 trillion, and IDR 24.5 trillion is approximately $30.3 \%$ of IDR 80.7 trillion. The total FSP realized is then IDR 64.4 trillion. Source: Ministry of Finance (2009)

The Existing Policy Scenario (SIM1): The existing policy scenario represents the initial situation in which the government has implemented the FSP using all five major instruments. The magnitude of the shock of each instrument equals the value of each instrument in the 2009 FSP (Table 1) and is proportionally equivalent to their relevant base in the 2009 state budget. With this setup, the following shocks are applied in this scenario:

(1) Personal income tax cut by $30.3 \%$ of base value.

(2) Corporate Income tax cut by $4.2 \%$ of base value.

(3) Indirect tax cut by $2.1 \%$ of base value.

(4) Increase in central government spending on infrastructure by $1.7 \%$ of base value. It is assumed that additional funding from abroad in the form of foreign debt is used to finance this extra infrastructure spending. However, the government has to repay the debt including interest of 5\% per annum, assuming a 3-year grace period.

(5) Cash transfer to the poor and nearly poor households (35\% lowest percentile of households) of $14.4 \%$ of base value.

As government spending on infrastructure is mainly allocated for trade and transportation-related sectors, it is also assumed that there will be a $1 \%$ reduction in the trade margin and transportation costs. In other words, the increase in government spending on infrastructure will increase efficiency by $1 \%$ in the trade and 
transportation sectors during the entire period (2009-2020). ${ }^{8}$ Therefore, an additional shock will be applied to the model through the efficiency parameters for four sectors; trade and land, water, and air transportation.

The fund for the FSP comes from the following sources. First, it comes from government borrowing or deficit. Since the government can only have a deficit as much as $3 \%$ of GDP by law, and it is difficult for the government to get international loans; the model assumes that the amount of international borrowing in 2009 was $10 \%$ higher than that of the previous year. ${ }^{9}$ Second, it comes from government savings, i.e., the amount of government savings in 2009 is lower than that in the previous year. Third, the government needs to fund some of the FSP budget by canceling spending for some other expenditures.

The Base Case (No-Policy) Scenario (SIM0): The base case is constructed by removing all instruments of the five policies in the Existing Policy Scenario (SIM1), i.e., removing the IDR 64.4 trillion stimulus package) to generate a situation in which there is no government intervention through the FSP.

The FSP through Personal Income Tax Cuts (SIM2): the government carries out the entire fiscal stimulus policy (the IDR 64.4 trillion stimulus package) only through personal income tax cuts. The FSP through Corporate Income Tax Cuts (SIM3): the government carries out the entire fiscal policy stimulus (the IDR 64.4 trillion stimulus package) only through corporate income tax cuts.

The FSP through Indirect Tax Cuts (SIM4): the government carries out the entire fiscal stimulus policy (the IDR 64.4 trillion stimulus package) only through indirect tax cuts. The FSP through Government Spending on Infrastructure (SIM5): the government carries out the entire fiscal stimulus policy (the IDR 64.4 trillion stimulus package) solely through government spending on infrastructure funded by external funding through foreign debt. While this means that more foreign debt, which has to be repaid by 2020 , is needed, efficiency in the trade and transportation sectors will improve by $1 \%$.

The FSP through Direct Cash Transfers to the Poor and Nearly Poor Households (SIM6): to maintain aggregate demand, the government carries out the whole fiscal stimulus (the IDR 64.4 trillion stimulus package) through cash transfers to the poor and nearly poor household groups. These groups are then expected to use this money for consumption.

\footnotetext{
${ }^{8}$ Meaning the Leontief coefficients of the production functions in trade and transportation sectors are decreased by $1 \%$ of their initial values. This number is based on the government's expectation on the effectiveness of this stimulus. The increase in productivity is relatively small and so it would not significantly drive the outcomes of the simulations.

${ }^{9}$ During regular years, the country's deficit has usually been relatively close to its limit. Hence, it is difficult for the government to expand its budget during a crisis by further increasing its deficit.
} 
Table 2 Short-term impact on macroeconomy for the year 2009

\begin{tabular}{|c|c|c|c|c|c|c|c|}
\hline \multirow[t]{2}{*}{$(\operatorname{In} \%)$} & \multirow[t]{2}{*}{ Variant } & \multicolumn{6}{|c|}{ Simulations } \\
\hline & & SIM1 & SIM2 & SIM3 & SIM4 & SIM5 & SIM6 \\
\hline \multirow[t]{2}{*}{ GDP } & Flexible wage & 0.016 & 0.001 & -0.010 & 0.092 & 0.023 & 0.003 \\
\hline & Sticky wage & 0.283 & 0.110 & 0.287 & 1.220 & 0.328 & 0.047 \\
\hline \multirow[t]{2}{*}{ Private consumption } & Flexible wage & 0.642 & 0.806 & 0.317 & 1.448 & 0.697 & 0.921 \\
\hline & Sticky wage & 1.089 & 0.922 & 0.630 & 2.596 & 0.953 & 0.963 \\
\hline \multirow[t]{2}{*}{ Government consumption } & Flexible wage & 0.241 & 0.134 & 1.909 & -0.387 & 6.259 & -2.923 \\
\hline & Sticky wage & 2.464 & 0.338 & 2.518 & 0.945 & 6.632 & -2.789 \\
\hline \multirow[t]{2}{*}{ Fixed investment } & Flexible wage & 0.125 & 0.146 & 2.595 & 0.043 & 0.242 & 0.902 \\
\hline & Sticky wage & 1.171 & 0.256 & 2.920 & 1.079 & 0.562 & 0.963 \\
\hline \multirow[t]{2}{*}{ Export } & Flexible wage & -0.371 & -1.052 & -2.009 & -1.513 & -0.411 & -1.013 \\
\hline & Sticky wage & -1.070 & -0.969 & -1.813 & -0.389 & -0.098 & -0.980 \\
\hline \multirow[t]{2}{*}{ Import } & Flexible wage & 0.524 & 0.812 & 1.390 & 1.142 & 0.923 & 0.842 \\
\hline & Sticky wage & 1.348 & 0.901 & 1.719 & 1.935 & 1.114 & 0.852 \\
\hline \multicolumn{8}{|l|}{ GRDP } \\
\hline \multirow[t]{2}{*}{ Sumatra } & Flexible wage & 0.011 & -0.003 & -0.008 & 0.072 & 0.019 & -0.002 \\
\hline & Sticky wage & 0.185 & 0.060 & 0.184 & 0.680 & 0.231 & 0.043 \\
\hline \multirow[t]{2}{*}{ Java-Bali } & Flexible wage & 0.020 & 0.002 & -0.014 & 0.094 & 0.026 & 0.012 \\
\hline & Sticky wage & 0.332 & 0.143 & 0.332 & 1.748 & 0.397 & -0.025 \\
\hline \multirow[t]{2}{*}{ Kalimantan } & Flexible wage & 0.015 & 0.005 & 0.016 & 0.185 & 0.015 & 0.010 \\
\hline & Sticky wage & 0.078 & 0.030 & 0.138 & -0.312 & 0.102 & 0.049 \\
\hline \multirow[t]{2}{*}{ Sulawesi } & Flexible wage & 0.006 & -0.003 & -0.009 & -0.011 & 0.019 & -0.020 \\
\hline & Sticky wage & 0.413 & 0.098 & 0.385 & 0.668 & 0.390 & 0.521 \\
\hline \multirow[t]{2}{*}{ Eastern Indonesia } & Flexible wage & -0.001 & -0.011 & -0.041 & 0.017 & 0.011 & -0.080 \\
\hline & Sticky wage & 0.446 & 0.095 & 0.427 & 0.491 & 0.299 & 0.739 \\
\hline
\end{tabular}

All figures resulted from the simulations are in percentage deviation from the base case (SIM0). The base case (SIM0) here refers to the situation without the presence of government intervention through fiscal stimulus packages (FSP). GRDP is the gross regional domestic product

\section{Results and discussion}

Tables 2, 3 show the short-term impact of the fiscal stimulus policy on macroeconomic variables under different scenarios and variants, i.e., the situation in 2009. The top row of each variable in Tables 2, 3 indicates the simulation outcomes under a flexible real wage rate (full-employment) assumption, while the second row (shaded) of each variable represents the simulation outcomes under a sticky real wage rate (non-full-employment) assumption. The long-term impacts are presented in Tables 4, 5 . 
Table 3 Short-term impact on poverty for the year 2009

\begin{tabular}{|c|c|c|c|c|c|c|c|}
\hline \multirow[t]{2}{*}{$(\operatorname{In} \%)$} & \multirow[t]{2}{*}{ Variant } & \multicolumn{6}{|c|}{ Simulations } \\
\hline & & SIM1 & SIM2 & SIM3 & SIM4 & SIM5 & SIM6 \\
\hline \multicolumn{8}{|l|}{ National: poverty } \\
\hline \multirow[t]{2}{*}{ Rural and urban } & Flexible wage & -0.363 & -0.281 & -0.158 & -0.618 & -0.227 & -0.665 \\
\hline & Sticky wage & -0.535 & -0.273 & -0.206 & -0.755 & -0.266 & -0.624 \\
\hline \multirow[t]{2}{*}{ Urban } & Flexible wage & -0.243 & -0.298 & -0.230 & -0.611 & -0.246 & -0.330 \\
\hline & Sticky wage & -0.396 & -0.287 & -0.272 & -0.585 & -0.297 & -0.302 \\
\hline \multirow[t]{2}{*}{ Rural } & Flexible wage & -0.459 & -0.268 & -0.100 & -0.624 & -0.212 & -0.932 \\
\hline & Sticky wage & -0.645 & -0.262 & -0.154 & -0.890 & -0.241 & -0.881 \\
\hline \multicolumn{8}{|l|}{ Regional: poverty } \\
\hline \multicolumn{8}{|l|}{ Sumatra } \\
\hline \multirow[t]{2}{*}{ Rural and urban } & Flexible wage & -0.170 & -0.141 & -0.056 & -0.270 & -0.120 & -0.273 \\
\hline & Sticky wage & -0.243 & -0.159 & -0.098 & -0.380 & -0.154 & -0.271 \\
\hline \multirow[t]{2}{*}{ Urban } & Flexible wage & -0.201 & -0.209 & -0.162 & -0.329 & -0.174 & -0.356 \\
\hline & Sticky wage & -0.338 & -0.224 & -0.194 & -0.495 & -0.225 & -0.330 \\
\hline \multirow[t]{2}{*}{ Rural } & Flexible wage & -0.153 & -0.103 & 0.004 & -0.236 & -0.089 & -0.226 \\
\hline & Sticky wage & -0.190 & -0.123 & -0.044 & -0.316 & -0.114 & -0.237 \\
\hline \multicolumn{8}{|l|}{ Java-Bali } \\
\hline \multirow[t]{2}{*}{ Rural and Urban } & Flexible wage & -0.230 & -0.326 & -0.180 & -0.786 & -0.252 & -0.255 \\
\hline & Sticky wage & -0.363 & -0.331 & -0.252 & -0.945 & -0.319 & -0.244 \\
\hline \multirow[t]{2}{*}{ Urban } & Flexible wage & -0.198 & -0.323 & -0.226 & -0.722 & -0.254 & -0.171 \\
\hline & Sticky wage & -0.333 & -0.314 & -0.290 & -0.651 & -0.320 & -0.170 \\
\hline \multirow[t]{2}{*}{ Rural } & Flexible wage & -0.263 & -0.329 & -0.133 & -0.853 & -0.249 & -0.341 \\
\hline & Sticky wage & -0.395 & -0.348 & -0.212 & -1.250 & -0.319 & -0.320 \\
\hline \multicolumn{8}{|l|}{ Kalimantan } \\
\hline \multirow[t]{2}{*}{ Rural and Urban } & Flexible wage & -0.521 & -0.182 & -0.036 & 0.318 & -0.145 & -1.792 \\
\hline & Sticky wage & -0.284 & -0.101 & -0.063 & 0.211 & -0.081 & -1.785 \\
\hline \multirow[t]{2}{*}{ Urban } & Flexible wage & -0.109 & -0.076 & -0.061 & 0.319 & -0.054 & -0.638 \\
\hline & Sticky wage & -0.156 & -0.081 & -0.073 & 0.271 & -0.069 & -0.470 \\
\hline \multirow[t]{2}{*}{ Rural } & Flexible wage & -0.754 & -0.242 & -0.023 & 0.318 & -0.196 & -2.445 \\
\hline & Sticky wage & -0.357 & -0.113 & -0.057 & 0.177 & -0.088 & -2.531 \\
\hline \multicolumn{8}{|l|}{ Sulawesi } \\
\hline \multirow[t]{2}{*}{ Rural and Urban } & Flexible wage & -0.505 & -0.166 & -0.119 & -0.304 & -0.164 & -3.748 \\
\hline & Sticky wage & -0.756 & -0.249 & -0.204 & -0.534 & -0.272 & -3.424 \\
\hline \multirow[t]{2}{*}{ Urban } & Flexible wage & -0.555 & -0.316 & -0.350 & -0.624 & -0.363 & -2.378 \\
\hline & Sticky wage & -0.829 & -0.351 & -0.429 & -0.797 & -0.445 & -2.431 \\
\hline \multirow[t]{2}{*}{ Rural } & Flexible wage & -0.485 & -0.107 & -0.028 & -0.177 & -0.085 & -4.289 \\
\hline & Sticky wage & -0.727 & -0.209 & -0.115 & -0.429 & -0.203 & -3.816 \\
\hline Eastern Indonesia & & & & & & & \\
\hline Rural and Urban & Flexible wage & -2.872 & -0.656 & -0.565 & -1.736 & -0.627 & -10.550 \\
\hline & Sticky wage & -4.577 & -0.266 & -0.269 & -1.541 & -0.259 & -12.112 \\
\hline Urban & Flexible wage & -1.454 & -0.550 & -0.874 & -1.047 & -0.621 & -5.079 \\
\hline & Sticky wage & -2.217 & -0.222 & -0.342 & -0.519 & -0.259 & -5.597 \\
\hline
\end{tabular}


Table 3 (continued)

\begin{tabular}{llllllll}
\hline (In \%) & Variant & \multicolumn{2}{l}{ Simulations } & & & \\
\cline { 3 - 7 } & & SIM1 & SIM2 & SIM3 & SIM4 & SIM5 & SIM6 \\
\hline Rural & Flexible wage & -3.406 & -0.696 & -0.449 & -1.996 & -0.630 & -12.613 \\
& Sticky wage & -5.467 & -0.283 & -0.242 & -1.926 & -0.259 & -14.569 \\
\hline
\end{tabular}

FSP is fiscal stimulus packages. All figures resulted from the simulations are the magnitude deviation from the base case (SIM0). The base case (SIM 0) here refers to the situation in the absence of government intervention through fiscal stimulus packages (FSP)

Table 4 Long-term impact on macroeconomy by the year 2020

\begin{tabular}{|c|c|c|c|c|c|c|c|}
\hline \multirow[t]{2}{*}{ (In \%) } & & \multicolumn{6}{|c|}{ Simulations } \\
\hline & & SIM1 & SIM2 & SIM3 & SIM4 & SIM5 & SIM6 \\
\hline \multirow[t]{2}{*}{ GDP } & 2020 & 0.148 & 0.589 & 0.700 & 0.585 & 0.306 & 0.621 \\
\hline & TPV & 0.091 & 0.331 & 0.482 & 0.331 & 0.198 & 0.375 \\
\hline \multirow[t]{2}{*}{ Private consumption } & 2020 & 0.322 & 0.742 & 0.839 & 0.739 & 0.867 & 0.770 \\
\hline & TPV & 0.298 & 0.548 & 0.652 & 0.584 & 0.769 & 0.595 \\
\hline \multirow[t]{2}{*}{ Government consumption } & 2020 & 0.391 & 2.439 & 2.528 & 2.435 & 0.513 & 2.464 \\
\hline & TPV & 0.249 & 2.105 & 2.337 & 2.066 & 0.490 & 1.937 \\
\hline \multirow[t]{2}{*}{ Fixed investment } & 2020 & 0.380 & 1.515 & 1.609 & 1.512 & 0.798 & 1.543 \\
\hline & TPV & 0.312 & 1.173 & 1.462 & 1.162 & 0.669 & 1.260 \\
\hline \multirow[t]{2}{*}{ Export } & 2020 & 0.233 & -0.204 & -0.070 & -0.209 & 0.884 & -0.165 \\
\hline & TPV & 0.165 & -0.536 & -0.405 & -0.569 & 0.791 & -0.481 \\
\hline \multirow[t]{2}{*}{ Import } & 2020 & 0.283 & 1.123 & 1.215 & 1.120 & 0.599 & 1.150 \\
\hline & TPV & 0.241 & 0.922 & 1.077 & 0.940 & 0.481 & 0.958 \\
\hline \multicolumn{8}{|l|}{ GRDP } \\
\hline \multirow[t]{2}{*}{ Sumatra } & 2020 & 0.137 & 0.553 & 0.659 & 0.550 & 0.282 & 0.584 \\
\hline & TPV & 0.084 & 0.310 & 0.452 & 0.309 & 0.182 & 0.351 \\
\hline \multirow[t]{2}{*}{ Java-Bali } & 2020 & 0.150 & 0.588 & 0.698 & 0.584 & 0.317 & 0.620 \\
\hline & TPV & 0.094 & 0.329 & 0.477 & 0.330 & 0.205 & 0.373 \\
\hline \multirow[t]{2}{*}{ Kalimantan } & 2020 & 0.173 & 0.771 & 0.914 & 0.765 & 0.332 & 0.812 \\
\hline & TPV & 0.106 & 0.447 & 0.640 & 0.451 & 0.207 & 0.503 \\
\hline \multirow[t]{2}{*}{ Sulawesi } & 2020 & 0.126 & 0.515 & 0.612 & 0.512 & 0.259 & 0.543 \\
\hline & TPV & 0.076 & 0.284 & 0.415 & 0.279 & 0.164 & 0.321 \\
\hline \multirow[t]{2}{*}{ Eastern Indonesia } & 2020 & 0.104 & 0.310 & 0.395 & 0.307 & 0.252 & 0.335 \\
\hline & TPV & 0.070 & 0.190 & 0.320 & 0.187 & 0.173 & 0.224 \\
\hline
\end{tabular}

All simulations reported are only for the flexible wage assumption. The 2020 columns present the year 2020 situation deviations in percentage from the base case (SIM0). The base case (SIM0) here refers to the situation without the presence of government intervention through fiscal stimulus packages (FSP). The TPV presents the deviation of total present value of each simulation during the 2009-2020 period from that of the base case. TPV is $\sum_{t=2009}^{2020} \frac{X_{t}}{(1+r)^{t}}$, where real interest rate (RIR) $(1.24 \%)$ is used the discount rate following Hur et al. (2010) and $X_{t}$ is the output variable, such as GDP, private consumption, government consumption, fixed investment, export, import, or RGDP of each region 
Table 5 Long-term impact on poverty by the year 2020

\begin{tabular}{|c|c|c|c|c|c|c|}
\hline \multirow[t]{2}{*}{$(\operatorname{In} \%)$} & \multicolumn{6}{|c|}{ Simulations } \\
\hline & SIM1 & SIM2 & SIM3 & SIM4 & SIM5 & SIM6 \\
\hline \multicolumn{7}{|l|}{ National: poverty } \\
\hline Rural and urban & -0.033 & -0.081 & -0.091 & -0.081 & -0.084 & -0.089 \\
\hline Urban & -0.021 & -0.068 & -0.074 & -0.068 & -0.049 & -0.073 \\
\hline Rural & -0.042 & -0.092 & -0.104 & -0.091 & -0.112 & -0.102 \\
\hline \multicolumn{7}{|l|}{ Regional: poverty } \\
\hline \multicolumn{7}{|l|}{ Sumatra } \\
\hline Rural and urban & -0.048 & -0.095 & -0.110 & -0.094 & -0.135 & -0.107 \\
\hline Urban & -0.006 & -0.024 & -0.026 & -0.024 & -0.012 & -0.025 \\
\hline Rural & -0.072 & -0.134 & -0.157 & -0.133 & -0.204 & -0.153 \\
\hline \multicolumn{7}{|l|}{ Java-Bali } \\
\hline Rural and urban & -0.031 & -0.081 & -0.089 & -0.081 & -0.076 & -0.084 \\
\hline Urban & -0.024 & -0.074 & -0.080 & -0.074 & -0.059 & -0.076 \\
\hline Rural & -0.037 & -0.089 & -0.098 & -0.088 & -0.094 & -0.092 \\
\hline \multicolumn{7}{|l|}{ Kalimantan } \\
\hline Rural and urban & -0.016 & -0.043 & -0.049 & -0.043 & -0.039 & -0.045 \\
\hline Urban & -0.008 & -0.032 & -0.035 & -0.032 & -0.017 & -0.033 \\
\hline Rural & -0.020 & -0.049 & -0.057 & -0.049 & -0.052 & -0.052 \\
\hline \multicolumn{7}{|l|}{ Sulawesi } \\
\hline Rural and urban & -0.019 & -0.059 & -0.065 & -0.059 & -0.047 & -0.061 \\
\hline Urban & -0.023 & -0.102 & -0.108 & -0.102 & -0.044 & -0.104 \\
\hline Rural & -0.018 & -0.043 & -0.048 & -0.042 & -0.048 & -0.044 \\
\hline \multicolumn{7}{|l|}{ Eastern Indonesia } \\
\hline Rural and urban & -0.032 & -0.113 & -0.122 & -0.113 & -0.070 & -0.115 \\
\hline Urban & -0.047 & -0.210 & -0.224 & -0.209 & -0.090 & -0.214 \\
\hline Rural & -0.026 & -0.076 & -0.083 & -0.076 & -0.063 & -0.078 \\
\hline
\end{tabular}

All simulations reported are for the flexible wage assumption only. All figures are in magnitude deviations from the base case in 2020

\subsection{Short-term impacts on national and spatial economies}

As shown in Table 2, the 2009 FSP (SIM1) has a positive role in stimulating the economy. In the short term, the GDP is higher compared to the base case (without the FSP) both under the flexible and the sticky wage rate variants. Under the flexible wage rate, the GDP will increase by $0.02 \%$ of its base case. Meanwhile, under the sticky real wage rate, the GDP will increase by $0.2 \%$ compared to its base case. Under the sticky real wage rate assumption, the FSP attracts more people to work, while the flexible wage rate assumes that the labour supply is constrained and so undermined the impact on output.

With the exception of exports, under the existing policy scenario, all other components of GDP increase compared to the base case. Personal income tax 
cuts combined with cash transfers immediately induce household spending as income increases. Meanwhile, indirect tax cuts and government spending on infrastructure directly affect production activities, thus increasing the demand for factor production (under the sticky wage rate assumption) and raising the factor income payment (under the flexible wage rate assumption) to households, which then reinforce the effect on private consumption.

The impact of the 2009 FSP on gross fixed investment is also positive. One important thing to note is that the impact of the FSP on gross fixed investment depends on the decline in government savings due to the tax cut policy and the increase in household and corporate savings as a result of the fiscal stimulus policy. The positive effect, as shown in Table 2, indicates the decrease in government savings is well compensated for by the increase in private savings, thus resulting in a higher gross fixed investment; in particular, under corporate income tax cut policy. The increase in efficiency due to government infrastructure spending also enables the private sector to invest more. Nevertheless, as shown in Table 2, the impact of this fiscal policy causes exports to decline. As aggregate demand increases as a result of the fiscal stimulus, the relative price of domestic goods increases, making them less competitive in foreign markets.

All five regions considered in this model would have experienced a slight downturn if the government had not implemented the FSP in 2009, except for Eastern Indonesia under the flexible wage rate assumption. As at the national level, the impact of the 2009 FSP on GRDP is more profound under the sticky real wage rate assumption than the flexible real wage rate assumption. Table 2 shows that, under the flexible wage rate assumption, the Java-Bali region gains the most from the FSP, followed by Kalimantan, Sumatra, and Sulawesi. Eastern Indonesia does not receive any benefit from the FSP. Under the sticky wage rate assumption, the Eastern Indonesia region gains the most, and followed by Sulawesi, Java-Bali, Sumatra, and Kalimantan. Different structures of labour demand and wages in these Indonesian regions cause spatial variations of benefits from the FSP.

The last five columns of Table 2 present the effect of the FSP under different policy scenarios. Overall, it seems that indirect tax cuts (SIM4) have the biggest impact on national GDP. It seems that reducing the allocative efficiency distortions is very important in boosting the growth of the economy. As mentioned before, this policy either increases the demand for factor production or raises the factor income payment to households, and at the end, it induces higher private consumption in the country. A comparable tax rate reduction in indirect tax, turns out, has a larger impact on the GDP compared to personal or corporate income tax cuts.

Under the flexible real wage rate assumption, the impact of personal income tax (SIM2) cuts on GDP is weak in the short term. An increase in private consumption caused by the policy instrument could not fully compensate the decline of exports due to a weaker global demand. Relatively weaker aggregate demand generated from this policy instrument leads to a weaker adjustment in the labour market. Under the sticky wage rate assumption, an adjustment in the labour market, i.e., laying of some workers, produces a higher output than that under the flexible wage rate assumption.

Corporate income tax cuts (SIM3) seem to have a relatively larger impact on output compared to personal income tax cuts. Tax savings gained from corporate 
income tax cuts mean that corporations have larger savings and hence larger investments. This is demonstrated by its positive effect on gross fixed investments compared to any other policy instrument under both the flexible and sticky real wage rate assumptions. These investments are good for future growth, but they do not have much positive impact in the short-term. These investments cannot compensate the decline in exports. In a full-employment assumption, this policy instrument induces lower wages and so produces lower output than those under the base case.

In the case of the cash transfer scenario (SIM6), the impact is slightly larger than that under the personal income tax cut scenario. This situation could be due to the fact that most of the beneficiaries of the cash transfer program (the poor and nearly poor) have liquidity constraints and are more likely to use the money for consumption rather than put the cash in saving (Bazzi et al. 2012). Compared to the indirect tax cut scenario, the impact of the cash transfer scenario is smaller. Cash transfers force the government to reduce other spending, thus causing a significant fall in government spending on goods and services; by $2.9 \%$ under the flexible real wage rate assumption and 2.8 under the sticky real wage assumption.

In the short term, government spending on infrastructure (SIM5) produces an approximately $0.02 \%$ higher GDP than under the base case (SIM0). The increase in this government spending helps industries to be competitive and so the drops in exports are not as high as in other policy scenarios.

\subsection{Short-term impacts on national and spatial poverty}

In line with the macroeconomic story, the 2009 FSP (SIM1) seems to also have a positive impact on welfare in Indonesia (Table 3). All five instruments combined have been able to sustain the purchasing power of the poor and nearly poor households, such that they can maintain or even increase their expenditure level. Personal income tax cuts and cash transfers have played an important role in sustaining households' purchasing power as their income increases. At the same time, indirect tax cuts and government spending on infrastructure have also strengthened households' purchasing power through production activities that lead to higher demand for input factors and factor income payments.

When comparing the relative effectiveness of each fiscal instrument, the FSP through cash transfers (SIM6) appears to be the most effective way to alleviate poverty, followed by indirect tax cut (SIM4). The FSP through cash transfers causes the poverty rate to decline by approximately $0.67 \%$ from the base case (without FSP). As expected, cash transfers targeted at the poor and nearly poor households directly boost the beneficiaries' purchasing power, thus enabling increased expenditure on goods and services. Indirect tax cuts (SIM4) lead to lower prices of commodity and to an increase in factor payments to households, Indirectly, this policy induces higher ability to the poor and nearly poor people to consume more.

As shown in Table 3, personal and corporate income tax cuts (SIM2 and SIM3) have relatively small effects on poverty rate reduction. In the case of personal income tax cuts, seeing as most household taxpayers are not considered poor, the impact on poverty rate reduction is relatively small. Corporate income tax cuts affect 
the capability of corporations to invest. This higher investment, however, has relatively small impact on lower income households, at least, in the short term. Similarly, the FSP through infrastructure spending (SIM5) also has a relatively small effect on poverty rate reduction as it is likely to have less impact on the poor in the short term.

Regarding regional poverty under the existing policy (SIM1), the effect seems to be positive across regions. Regions with higher percentage of poor people seem to benefit more from the policy. It is expected that income inequality within the country would reduce. Cash transfers (SIM6) show the greatest benefit in those regions with a high proportion of poor people. Thus, Eastern Indonesia, Sulawesi, and Kalimantan gain the most benefit from cash transfers in terms of poverty rate reduction.

Tax instruments (SIM2, SIM3, and SIM4) tend to provide more benefits to regions with a large proportion of their economy in labour-intensive sector (e.g., agriculture, manufacturing, and services). Meanwhile, Kalimantan's economy by mid-2000s was mostly coal, oil, and gas mining, which are capital intensive. Indirect tax cuts do not provide much benefit to households on the island in the short term. Kalimantan receives most of its food supplies from other islands, particularly Sumatra, Java, and Sulawesi. Increasing demands of food in those other islands increase relative food prices in Kalimantan, which then results in a higher poverty rate compared to the base case.

Different sectoral structures and initial poverty conditions across regions in Indonesia spatially vary the poverty impacts of the country's FSP policy.

\subsection{Long-term impacts on national and spatial economies}

All estimated figures in Table 4 are for the flexible wage rate assumption only. The 2020 columns present the year 2020 situation deviations in percentage from the base case (SIM0). The TPV presents the deviation of the total present value from 2009 till 2020 for each scenario from the situation in the base case. Calculation of their present value is using the real interest rate (RIR) of $1.24 \%$ as the discount rate, in accordance with Hur et al. (2010).

As shown in Table 4, in the long term, the 2009 FSP (SIM1) is likely to produce a higher 2020 GDP by approximately $0.15 \%$ and a higher total present value of GDPs from 2009 till 2020 by approximately $0.9 \%$ than those of the base case, respectively. All GDP components are also likely to have a positive sign, confirming the positive role of the 2009 FSP in stimulating the economy. Tax cuts combined with extra government spending on infrastructure and cash transfers provide important support in sustaining consumers' purchasing power amidst the weakening global economy in 2009 and through to 2020.

Gross fixed investment is stronger in the long term. It is approximately $0.38 \%$ higher in 2020 than the base case, or approximately $0.31 \%$ for the whole period of 2009-2020. Corporate income tax cuts lead to a much higher level of investment and increase production capacities and so factor income payments to households 
and government. Household and government consumptions in the long term also increase following higher financing capacity as overall aggregate demand increases.

Export performances are also recovering under the existing policy. By 2020, exports are approximately $0.23 \%$ higher than the situation in the base case. Stronger domestic production activities lead to a greater competitiveness for export commodities.

Looking at the outcomes of each fiscal instrument considered in this paper, corporate income tax cuts (SIM3), cash transfers to the poor and nearly poor (SIM6), personal income tax cuts (SIM2), and indirect tax cuts (SIM4) seem to contribute a more profound and longer lasting effect than infrastructure construction instrument. The tax cut and cash transfer policies in the long term, besides increase private consumptions, also induce higher government consumption. Infrastructure construction increased government consumption in the short term, but not for long. All tax cuts and cash transfer also provide higher both private and government savings as well to use for investment, which accumulates and thus benefits the economy in the long-term.

Interesting to compare are the performances of corporate tax cut (SIM3) and indirect tax cut (SIM4) policies. In the short term, the corporate tax cut policy boosts investments but not so much private consumptions. In contrast, the indirect tax cut policy increases significantly private consumptions, but not so many investments. It can also be observed that the indirect tax cut policy performs better than the corporate tax cut policy in the short term. In the long term, however, the accumulation of investments due to the corporate tax cut policy benefits the economy more.

Both personal income tax cuts (SIM2) and cash transfers to the poor (SIM6) increase private consumptions in the short term. The private income tax cut policy benefits the richer part of the population, while the cash transfer policy is for the poor. In the long-term, it can be seen that strengthening abilities of the poor to consume more would benefit the economy more than strengthening the rich's abilities to consume. In the case of Indonesia, the consumption pattern of the poor, which is mostly heavy toward food consumption, boosts the economy stronger than that of the rich.

The long-term impact of FSP spatially across regions varies. Kalimantan benefits the most and Eastern Indonesia benefits the least. In general, regions with more capital-intensive industries benefit more. Kalimantan's economy by mid-2000s was mostly coal and oil-gas-mining activities with intensive capital invested. Eastern Indonesia has some mining industries too. However, mining activities in Eastern Indonesia are typically a much more enclave economic activities than coal-mining activities in Kalimantan. Sources of livelihood for majority population in Eastern Indonesia are in low capital agriculture and fishery sectors.

\subsection{Long-term impacts on national and spatial poverty}

Table 5 shows the long-term effect of the FSP on poverty under the flexible wage rate assumption. Under the existing policy (SIM1), national poverty rate decreases by $0.03 \%$ compared to the base case by 2020 . In line with the short-term results, the 
FSP is overall biased towards rural areas, where it could decrease the poverty rate by $0.04 \%$, as opposed to $0.02 \%$ in urban areas.

At the national level, corporate income tax cuts (SIM3) and cash transfers (SIM6) are the most effective ways to reduce poverty. Unlike in the short-term outcomes, in the long term, it seems the corporate income tax cut policy has a slightly higher impact on poverty than cash transfers at the national level. In rural areas, this effect is greater than in urban areas, suggesting that better higher investments are an important factor in reducing poverty rate in rural areas. This result is particularly due to that more job creations could happen with high investments.

One important point to note concerning the distributional effect across regions is that high increase in investment, while it is good for the economy, does not always translate into effective poverty rate reduction. High investment in Kalimantan's mining activities seems to have relatively small impact in reducing poverty rate in the island. It can be seen in Table 5 that Kalimantan experiences the least poverty rate reduction compared to other island groups.

In areas where majority of the population are in labour-intensive sectors, such as agriculture and services, the FSP are able to able to reduce poverty rate more compared to are with more capital-intensive sectors. It can be seen that the FSP reduces poverty rate more in Sumatra and Eastern Indonesia.

Relatively effect of infrastructure spending (SIM5) in less-developed regions such as Kalimantan, Eastern Indonesia, and Sulawesi, on poverty is smaller than those in more-developed regions like Sumatra and Java-Bali. This indicates that, while improving infrastructure in less-developed regions are important, increasing investment in labour-intensive sectors is one of the major economic hurdles in any poverty alleviation program. People living in these regions need more jobs and higher payments to be able to graduate from poverty.

\section{Conclusion}

Indonesia, like other countries, has responded to the 2008 global financial crisis (GFC) by allowing fiscal policy to take a more expansionary stance. The Indonesian government launched fiscal stimulus packages (FSP) in 2009 that amounted to approximately US\$7 billion (1.4\% of GDP). Compared to FSPs taken by developed countries, the Indonesian government could not easily obtain funding sources from international institutions to fully finance its FSP. The government had to reallocate some of its expenditure to fund the FSP. Many developing countries would be in a similar situation as Indonesia each time a global crisis struck. Discussion on how exactly the Indonesian 2009 FSP affects its economy has yet been supported by any empirical evidence. This paper utilizes a recursive inter-regional CGE, the IRSA-Indonesia5, model to empirically assess the impact of this Indonesian FSP on its economy.

Based on the simulation results of the Indonesian case, several conclusions can be drawn with regard to the roles of an FSP in softening the impact of a GFC on the economy. First, an FSP most likely has a positive effect in mitigating the effect of a GFC despite it is not fully funded through external sources. In the case of Indonesia, it can be seen that the FSP had an overall positive impact on 
stimulating the economy despite the present of the 2008 GFC, as indicated by the positive effect on GDP both in the short and long terms. In the short term, the combination of personal income tax cuts, indirect tax cuts, and cash transfers contributes to the increase in private consumptions, while corporate income tax cuts and government spending on infrastructure stimulate the economy through investments and government consumption, respectively. The positive effect of the FSP in the long term is mainly through tax cuts, particularly corporate income tax cuts, which encouraged private sectors to invest more.

Second, in the short term, an FSP might have a greater effect on the economy under the fixed-wage rate regime than the standard regime of a flexible wage rate. This can be readily explained as in the flexible real wage rate assumption, labour supply is constrained (fixed) and the wage rate treated as the equilibrating variable to clear the labour market. Meanwhile, under the sticky real wage assumption, the amount of employed labour may be adjusted to any policy changes. An FSP induces increases in labour supply, which in turn boosts the economy through the increase in production activities.

Third, an FSP could have an uneven spatial distributional effect on output across regions in the short term, but this could most likely even out in the long-term. Since there is no region-specific target under an FSP, the effect will depend upon the proportion of an FSP that is allocated to each region, as well as the region's dependence on sectors targeted in the FSP. Different sectoral structures; i.e., labour demands and wages among regions also cause spatial variations of benefits from the FSP.

The Indonesian case shows that, under the existing policy (the 2009 FSP), Java-Bali seems to gain more benefits than other regions in the short term. However, in the long term, due to more spread out capital invested throughout the regions, other regions benefit from the FSP as much as Java does.

Fourth, looking at the impact on poverty rate reduction, it seems that an FSP as a whole could have a poverty alleviating impact both in the short and long-terms. Observing the Indonesian case, this impact spatially is more profound in relatively less-developed regions such as Eastern Indonesia than in more-developed regions such as Java, Bali, and Sumatra in the short-term. In the long term, poverty rates in regions with large labour-intensive sectors such as Java-Bali and Sumatra reduce more than regions with less labour-intensive sectors such as Kalimantan and Sulawesi.

Fifth, while in the short term, indirect tax cuts appear to be the most effective way of stimulating aggregate demand, corporate income tax cuts have the largest impact on stimulating the economy in the long-term, as indicated by the magnitude of the GDP. The capital accumulated from higher corporate savings leads to a larger domestic output. It is also worth highlighting that in the long term, while corporate income tax cuts provide the greatest boost to national output, it produces the worst distributional effect because of its relative bias towards capital intensive regions. Thus, the gap between the lagging region of Indonesia, Papua, with other regions could become larger. infrastructure spending allows less-developed regions to draw level with more advanced regions.

Finally, if the government's top priority is poverty alleviation, cash transfers seem to the optimal choice, since it has the largest impact on poverty rate reduction in the short term and the second highest in the long term. Cash transfers are also relative-spatially 
biased towards less-developed regions, as they induce larger poverty rate reductions in those regions compared to more-developed regions, both in the short and long terms.

Overall, based on the Indonesian case study, it can be concluded that if the country had not implemented an FSP, its economy would have declined, and the poverty rate would have increased. The results of this paper could certainly be a lesson for governments in developing countries, for designing fiscal policies in response to current slow global economic growth and ensuring that the spatial benefits of these policies are relatively equal.

\section{Appendix}

See Appendix Table 6.

Table 6 Lists of sectors and factor inputs

\begin{tabular}{|c|c|c|c|}
\hline \multicolumn{4}{|c|}{ Sectors } \\
\hline 1 & Rice & 19 & Cement \\
\hline 2 & Other food crops & 20 & Basic metal \\
\hline 3 & Estate crops/plantations & 21 & Metal products \\
\hline 4 & Livestock & 22 & Electrical equipment and machinery \\
\hline 5 & Forestry & 23 & Vehicle \\
\hline 6 & Fishery & 24 & Other industries \\
\hline 7 & Oil, gas and geothermal mining & 25 & Electricity, gas and clean water \\
\hline 8 & Coal and other mining & 26 & Construction \\
\hline 9 & Oil refinery & 27 & Trade \\
\hline 10 & Palm oil processing & 28 & Hotel and restaurant \\
\hline 11 & Marine capture processing & 29 & Land transportation \\
\hline 12 & Food and beverage processing & 30 & Water transportation \\
\hline 13 & Textile and textile products & 31 & Air transportation \\
\hline 14 & Footwear & 32 & Communication \\
\hline 15 & Wood, rattan and bamboo products & 33 & Financial sector \\
\hline 16 & Pulp and paper & 34 & Government and military \\
\hline 17 & Rubber and rubber products & 35 & Other services \\
\hline 18 & Petrochemical products & & \\
\hline \multicolumn{4}{|c|}{ Factor inputs } \\
\hline 1 & Formal agricultural labour & 7 & Capital \\
\hline 2 & Informal agricultural labour & 8 & Land \\
\hline 3 & Formal skilled labour & & \\
\hline 4 & Informal skilled labour & & \\
\hline 5 & Formal unskilled labour & & \\
\hline 6 & Informal unskilled labour & & \\
\hline
\end{tabular}




\section{References}

Adelman I, Robinson S (1988) Macroeconomic adjustment and income distribution: alternative models applied to two economies. J Dev Econ 29(1):1-22. https://doi.org/10.1016/03043878(88)90069-7

Adelman I, Yeldan E (2000) The minimal conditions for a financial crisis: a multiregional intertemporal CGE model of the Asian crisis. World Dev 28(6):1087-1100. https://doi.org/10.1016/S0305 $-750 \mathrm{X}(00) 00014-0$

Basri MC, Rahardja S (2010) The Indonesian economy amidst the global crisis: good policy or good luck. ASEAN Econ Bull 27(1):77-97. https://www.jstor.org/stable/41317110

Bazzi S, Sumarto S, Suryahadi A (2012) Evaluating Indonesia's unconditional cash transfer, final reportinternational initiative for impact evaluation. https://www.business.uwa.edu.au/_data/assets/pdf_ file/0004/2053084/Bazzi,-Sumarto,-Suryahadi-3ie-Report-March-2012.pdf

Corden WM (2010) The theory of fiscal stimulus: how will a debt-financing stimulus affect the future? Oxf Rev Econ Policy 26(1):38-47. https://doi.org/10.1093/oxrep/grq001

Corden WM (2011) Ambulance economics: the pros and cons of fiscal stimuli. Open Econ Rev 22(2):235-245. https://doi.org/10.1007/s11079-011-9199-z

Dervis KJ, de Melo J, Robinson S (1982) General equilibrium models for development policy. Cambridge University Press, Cambridge. https://documents.worldbank.org/curated/en/386191468765592396/ pdf/multi-page.pdf

Diao X, Zhang Y, Chen KZ (2012) The global recession and China's stimulus package: a general equilibrium assessment of country level impacts. China Econ Rev 23(1):1-17. https://doi.org/10.1016/j. chieco.2011.05.005

Dixon PB, Parmenter BR, Sutton J, Vincent DP (1982) ORANI: a multisectoral model of the Australian economy. North-Holland, Amsterdam

Giesecke JA, Schilling C (2010) The economic impact of the New Zealand fiscal stimulus package. NZ Econ Papers 44(3):231-257. https://doi.org/10.1080/00779954.2010.522162

Hemming R, Kell M, Mahfouz S (2002) The effectiveness of fiscal policy in stimulating economic activity - a review literature. IMF working paper no. 02/208. International Monetary Fund, Washington D.C. https://www.imf.org/external/pubs/ft/wp/2002/wp02208.pdf

Hur S-K, Mallick S, Park D (2010) Fiscal policy and crowding out in developing Asia. ADB Economics working paper series no. 222. Asian Development Bank, Manila. https://www.adb.org/sites/default/ files/publication/28271/economics-wp222.pdf

IMF (International Monetary Fund) (2010) The world economic outlook: rebalancing growth. International Monetary Fund, Washington D.C. https://www.imf.org/en/Publications/WEO/Issue s/2016/12/31/Rebalancing-Growth

IMF (International Monetary Fund) (2011) The world economic outlook: slowing growth, rising risks. International Monetary Fund, Washington D.C. https://www.imf.org/en/Publications/WEO/Issue s/2016/12/31/Slowing-Growth-Rising-Risks

Johansen L (1960) A multi-sectoral study of economic growth. North-Holland Publishing Company, Amsterdam

Kim E, Kim K (2002) Impact of regional development strategies on growth and equity of Korea: a multiregional CGE model. Ann Reg Sci 36:165-180. https://doi.org/10.1007/s001680100071

Lambert S, Schneider H, Suwa A (1991) Adjustment and equity in Cote de'Ivoire: 1980-1986. World Dev 19(11):1563-1576. https://doi.org/10.1016/0305-750X(91)90006-4

Leigh A (2012) How much did the 2009 Australian fiscal stimulus boost demand? Evidence from household-reported spending effects. BE J Macroecon 12(1):1-22. https://doi. org/10.1515/1935-1690.2035

Lofgren H, Harris RL, Robinson S (2002) A Standard Computable General Equilibrium (CGE) Models in GAMS. Microcomputers in Policy Research No. 5, IFPRI, Washington, DC. https://www.ifpri .org/publication/standard-computable-general-equilibrium-cge-model-gams-0

Liew LH (1981) A multi-regional multi-sectoral general equilibrium model of the Australian economy. PhD Thesis, Monash University, Melbourne

Ministry of Finance (2009) Mitigating global crisis impact through fiscal stimulus program. Ministry of Finance of the Republic of Indonesia, Jakarta

Patunru AA, Zetha E (2010) Indonesia's savior: fiscal, monetary, of luck? Public Policy Rev 6(4):721-740 
Resosudarmo BP, Wuryanto LE, Hewings GJD, Saunders L (1999) Decentralization and income distribution in the inter-regional Indonesian economy. In: Hewings GJD, Sonis M, Madden M, Kimura Y (eds) Advances in spatial sciences: understanding and interpreting economic structure. SpringerVerlag, Heidelberg, pp 297-315. https://www.springer.com/gp/book/9783540660453

Resosudarmo BP, Nurdianto DA, Hartono D (2009) The Indonesian inter-regional social accounting matrix for fiscal decentralization analysis. J Indones Econ Bus 24(2):145-162. https://jurnal.ugm. ac.id/jieb/article/view/6321

Resosudarmo BP, Yusuf AA, Hartono D, Nudianto DA (2011) Regional Economic Modelling for Indonesia: Implementation of IRSAINDONESIA5. J of Indones Econ Bus 26(3):287-309. https://jurna 1.ugm.ac.id/jieb/article/view/6259

Robinson S (1991) Macroeconomics, financial variables, and computable general equilibrium models. World Dev 29(11):1509-1525. https://doi.org/10.1016/0305-750X(91)90003-Z

Shapiro M, Slemrod J (2003) Did the 2001 tax rebate stimulate spending? Evidence from taxpayer surveys. Tax Policy Econ 17:83-109. https://www.jstor.org/stable/20140505

Thorbecke E (1991) Adjustment, growth and income distribution in Indonesia. World Dev 19(11):15951614. https://doi.org/10.1016/0305-750X(91)90008-6

Tokunaga S, Resosudarmo BP, Wuryanto LE, Dung NT (2003) An inter- regional CGE model to assess the impacts of tariff reduction and fiscal decentralization on the regional economy. Stud Reg Sci 33(2): $1-25$

Yusuf AA, Resosudarmo BP (2015) On the distributional impact of a carbon tax in developing countries: the case of Indonesia. Environ Econ Policy Stud 17(1):131-156. https://doi.org/10.1007/s1001 8-014-0093-y

Zhou S, Shi M, Li N, Yuan Y (2011) Effects of Chinese economic stimulus package on economic growth in the post-crisis China. Econ Res Int 2011:1-11. https://doi.org/10.1155/2011/492325

Publisher's Note Springer Nature remains neutral with regard to jurisdictional claims in published maps and institutional affiliations. 